\title{
Understanding World Music Festivals as Sites of Musical Education - An Ethnographic Approach
}

\author{
Peter Lell \\ University of Music Franz Liszt Weimar \\ peter.lell@hfm.uni-weimar.de
}

\begin{abstract}
World music festivals connect musicians with new audiences, offering possibilities for manifold forms of musical interaction. Festivals also offer sites where the discourse of 'world music' itself is reproduced for an attending audience. My ethnographic research uncovered such processes of interaction between festival visitors, musicians and the festival environment. This paper examines those processes and raises a particular polemic: what is gained from interpreting world music festivals as sites of musical education? Drawing on academic literature about learning popular music (Green 2002, Schippers 2010) and data from ethnographic fieldwork conducted at WOMAD, UK and the Africa Festival, Germany, I suggest that musical appreciation at festivals is a form of music education. The notion of 'music education' is extended and a model outlined providing various formative and descriptive parameters for the research topic. Several typologies for listening to and encountering the perceived music are described, constituting valuable forms of music learning. Further, the concept of 'world music' and the visitors' self-reflexivity about their own listening practices at music festivals is analysed to demonstrate how participants become critically aware of underlying discrepancies between perception and discourse. The findings outline that world music festivals can be seen as sites of musical education, and further suggestions are provided for this fruitful framing of the educational possibilities within music festival studies.
\end{abstract}

KeYWORDS: World Music Festivals, Music Education, Festival Ethnography, Qualitative Research

\section{Introduction}

Music festivals are of growing interest today. Facing the digital media world and the severe changes in the ways music is consumed, the music festival becomes more significant for music industries, music audiences and music studies (McKay 2015: 8). For the music industries, festivals are becoming one of the most profitable 
sectors, and for music audiences, festivals are of increasing importance to the experience of live music (Anderton 2018: 1). This change has led to a growing interest in music festival research, with a developing field of music festival studies, which is to be seen "as distinct from the broader fields of event management, event studies and tourism studies", which already exist in large variety. As Anderton (2018: 2) states, "[M]usic festival studies is interdisciplinary in nature and encompasses a wide range of theories and perspectives". In this article, I consider perspectives of music educational theories, and apply them to the context of world music festivals. Concretely, I want to scrutinize the music educational values of world music festivals.

When speaking about music education, general readers would likely imagine formal, institutional places of learning like public schools, music schools or universities. These formal institutions are connected to the legitimation and the achievement of being musically educated, and are often associated with the acquisition of practical musical skills with instruments, ensembles or composition. This echoes the idea of music education that is foregrounded in academic literature: "Until recently, formal learning practices have dominated attention and research agendas in music education. However, the continuum of lifelong music learning necessitates an awareness of the manifold ways of learning." (Veblen 2012: 245)

Much of the literature on music education (McPherson and Welch 2012; Colwell and Richardson 2002; Swanwick 2016) as well as multicultural music education (Schippers 2010; Campbell 2004; Solis 2004; Volk 1998) focuses on education in formal settings. In the field of popular music studies, however, a great deal more attention has been paid to informal learning processes of musicians (See Green 2002). This paper explores the informal contexts of music education involved in attending a music festival, particularly, the world music festival. World music festivals are quite a recent phenomenon, spreading widely since the emergence of the commercial genre of 'world music' in 1987 (Frith 2000; Feld 2000). While not inventing new music, the world music genre connected particular kinds of music with a new and larger audience. (1)

Situating world music festivals within music festivals in general, the first predecessors may be found as early as in the 11th century's troubadour guilds festivities or the "commercial and non-commercial festivals devoted to music [...] staged in Britain since the seventeenth and eighteenth centuries" (Anderton 2018: 4; Duffy 2019: 304). More direct predecessors of the world music festival may be found in exhibitions such as the famous World Expo in Paris in 1889, the first musical gatherings of the North American folk song and handicraft festivals in the early 20th century, or the folk and rock music festivals of the 1960s and 1970s (Näumann 2017: 206-207; McKay 2015: 3-4). As probably the first world music festival, WOMAD was founded in 1982 and set a standard in the evolution of the genre and its quickly gaining popularity. Continuing and extending this idea, world music festivals constitute places of encounter between global musicians and audiences at a local festival site. They offer possibilities of exchange and interaction and, moreover, shape the idea of something perceived as 'world music'. Going one step back, what characterizes music festivals in relation to other types of musical performances?

When attending music festivals, the audience is confronted with various artists in a row, which they also might have not intended to encounter. Music festivals are often described as a "collection of live performances" (Paleo and Wijnberg 2006: 51) providing an "intermediary between producers and consumers" (ibid.: 52) of music. They usually take place outdoors and over several days creating an immersive experience with music at its centre. Judith Mair offers this definition: 
Therefore, perhaps an appropriate, if lengthy, definition of festivals might be short term, recurring, publicly accessible events that usually celebrate and / or perform particular elements of culture that are important to the place in which they are held or the communities which hold them; that provide opportunities for recreation and entertainment; and that give rise to feelings of belonging and sharing. (Mair 2019: 5)

This fruitful setting of interaction (cf. Brás 2019: 264; Anderton 2018: 163) between the festival environment and visitors of world music festivals raises the following questions: Can the interactions between the environment and the visitors of world music festivals be described as music educational experiences? What notions of 'world music' are mediated, and in what particular ways? A selection of two music festivals has been taken as case studies for this research, the first being WOMAD, Charlton Park, UK, and the second, the Africa Festival, Würzburg, Germany. Ethnographic fieldwork was conducted on both, and research data, with an emphasis on qualitative interviews with festival visitors, was collected.

The existing literature that was found on world music festivals (Taylor 2017; Leggewie 2017; Amico 2014; Bohlman 2002; Hutnyk 1998) and on music educational experiences at festivals (Karlsen and Brändström 2008, Snell 2005) provided the first glimpses for my research field. However, only a couple were utilising qualitative ethnographic methods (Amico 2014, Hutnyk 1998). Those dealing with education had quite different methodological approaches, research goals, or argumentation styles (Karlsen and Brändström 2008, Snell 2005). Snell's work (2005) focuses on the music educational values of the OM music festival in Canada. Although Snell's valuable approach resembles my questions, she is not connecting her work with existing theories and discourses of music education and festival studies, nor is she aiming to create a framework that would be transferable to festivals other than her case study.

This article is structured as follows. First, ideas about music education are discussed, before the methodology of data collection and a brief introduction to the case studies is given. Subsequently, I ask if world music festivals are seen as sites of musical education and then, constituting the main part of my research, how they can be understood as such. Drawing on relevant literature in the field of world music education (Campbell 2004; Schippers 2010) and learning practices of popular musicians (Green 2002), as well as on the ethnographic data collected, I argue that the musical appreciation at world music festivals is a form of education suited to music festivals, and to their audiences' engagement with new forms of music and culture. Facilitating the complexity of this research argument as well as dealing with the lack of a fitting terminology for this field, music festivals functioning as places of musical education will initially be considered without the implications of 'world music'. This will be approached in a following section before finally, the results will be brought together re-approaching the research question.

\section{Ideas of Music Education}

Music education is most often seen in the context of conventional institutions such as schools, music schools, universities, or conservatories (McPherson and Welch 2012; Colwell and Richardson 2002; Swanwick 2016; Schippers 2010: vii-viii). This formal music education has recently been challenged by different concepts of "non-formal" and "informal" music education (Veblen 2012: 246) which, however, at best seem to represent a niche within the broader discourse. Not very different 
from that, the discourse of multicultural music education has favoured formal institutional concepts, even though the addressed musical practices often originate in informal ways of learning (Schippers 2010; Campbell 2004; Reimer 1991; Volk 1998). Apart from that, and especially in the contexts of folk music and world music, there are also concepts of education involving community music practices and group learning contexts (Schippers 2010: 92-97; Koopman 2007). Nonetheless, the idea of a teacher person, an "animateur" (Schippers 2010: 94) or "facilitator" (Koopman 2007: 155-157) is also central here, and the educational approach, therefore, is still close to that of formal institutions.

One of the more interesting concepts of music learning is found in a study on the most widespread music of today, popular music. In her influential study on the learning practices of popular musicians, Lucy Green (2002) outlines the ways they acquire the knowledge and the skills needed to become musicians. For many popular musicians, formal music education plays only a minor role, if any at all. Instead, peer-to-peer or self-taught approaches are more common. Green's study shows that popular musicians utilize a range of practices to learn on their own, without formal guidance or teacher authorities, which she calls informal music education.

Huib Schippers (2010) describes similar learning practices in musical traditions of the world, where large parts of music education can be found to function without a formal teacher or curriculum, but in informal, holistic, ways (Schippers 2010: 8193). These models are indicators that music education as a concept can have broader scope than the dichotomy of teacher-student found in formal institutions.

In this work, a further step is to be taken, not only away from formal institutions, as did Green or Schippers, but also beyond the learning practices of practicing musicians. Stressing the common idea of music education, I want to scrutinize if attendance at music festivals, and more concretely world music festivals, can be seen as a musical educational experience. For that, I am taking ideas from Green's How Popular Musicians Learn (2002), Schippers' Facing the Music (2010) as well as Campbell's Teaching Music Globally (2004). Despite their different foci, these ideas constitute a fertile ground for perspectives on music education in music festival settings. Lucy Green (2002) extends the idea of music education by describing in detail the informal learning approaches of popular musicians, and, furthermore, explains how musicians are not learning in formal institutions or being taught by a teacher, but instead are being led "foremost by the music [recordings]" themselves (Green 2002: 209).

Despite the new dimensions of music education Green and Schippers are outlining, they both talk explicitly about practicing musicians. My aim is to extend the idea of music education beyond practicing musicians, and towards the visitors of music festivals and their musical appreciation. I want to find out how the attendance at music festivals can be described as an educational experience with transformative possibilities.

\section{Methodology and Introduction to the Festivals}

The case studies for this research are the two festivals WOMAD (The World of Music and Dance) Charlton Park, UK and the Africa Festival Würzburg, Germany. From the numerous festivals presenting world music in Europe and the world, those two were selected for their high reputation among world music festivals, a promising appearance on websites and social media, being geographically within reach, and the dates of the festivals to be fitting into the timeframe of the research. 
WOMAD is especially successful as one of first world music festivals in the world that is ongoing, and has off-shoots in over 26 other countries.

The Africa Festival which has been chosen as the second case study is also one of the oldest festivals for 'world music' (founded in 1989), although in this case, the festival is identified with 'African music'. African music seems to constitute a large part of world music. Authors such as Keith Howard suggest that " $40 \%$ or more of world music [would] (...) always [have] been from Africa and the African diaspora" (Howard 2009: 8). Furthermore, the festivals do present similar musicians as well as utilizing similar ways of presenting and promoting their events.

The chosen festivals are of course not representative of all world music festivals in the world, or even in Europe. This research is based on ethnographic fieldwork conducted at the two festivals in 2017. I attended each of them for 3 full days, conducting participant observation and interviews with festival visitors.

The interviews were conducted using a semi-structured approach, with the questions addressing the interviewees' ideas and understandings of, and affiliation with world music and festivals. All in all, 21 in-depth interviews were conducted, 11 of them at the Africa Festival, and 10 of them at WOMAD. In the following presentation of the data, I have drawn equally on my own ethnographic observations as well as on the statements from my interviewees.

\section{Festivals as Sites of Music Education}

World music festivals might seem an odd choice for a discussion of music education, given that they are not seen primarily as places of education, and do not present themselves as such. Comparing them with the usual places of musical education, there is no teaching authority, nor is there a curriculum with specific goals or any kind of assessment. Also, there are no fixed methods or correct ways of experiencing or learning (cf. Schippers 2010: 81-83). Nonetheless, there are also similarities focused more on how learning works, and less on how teaching does.

At WOMAD, a number of musical workshops were offered. A few of those were instrumental workshops (kora, xylophone and gamelan), and a larger number were group workshops with musicians or bands. The latter were promoted explicitly as opportunities to "delve deeper into the music, the moves, and the motivations of some of the amazing artists performing at the festival, and (...) learn a new skill $(\ldots)^{\prime \prime}$ (WOMAD website 2018). While from my observations, as well as participation in some of these workshops, they seemed suitable to gain basic knowledge about the instruments, the musicians, and their music, for the majority of the festival visitors they were not relevant. Of all the festival visitors, only a few attended them, and none of my interviewees took part in any of the workshops, even though some, such as Derek, were keen to: "I always intend to, but then always end up... [not going]." (2017) This possible educational experience seemed of minor importance for most attending the festivals.

The Africa Festival, in contrast, had no formal music educational claims or places. This, however, was balanced by an unexpected discovery at the camping site, where visitors met and informally gathered in music ensembles, bringing their own instruments, and playing music for their own purposes. For the most part, the music practiced would be called West-African percussion music. This musical opportunity of course was part of the superordinate institution 'Africa Festival', neither planned nor maintained by the festival organizers, but rather initiated by the visitors themselves. 
The instrumental and group workshops at WOMAD, and the camping site musical gatherings at the Africa Festival, can be compared to the entry stages of music education as described in the school curriculum for world music study in a school setting, at community music workshops, or as part of popular music education (cf. Campbell 2004; Green 2002). However, those possibilities to participate practically in music making only impact a minority of the festival visitors, and, in general, seemed not to be very relevant for most of the attendees. This led me to a more challenging question: Is it possible to find ideas of music education, which are addressing the learning of festival visitors, that are not bound to places with explicit educational claims or associated with practical music making?

\section{Extending Music Education}

In this section, I consider the significance of musical appreciation as an aspect of musical education by relaying both the ethnographic accounts of the visitors and my own accounts. Drawing on Green (2002), and the ethnographic data from my research, I consider how practices of perception shaped the festival goers' experiences. First, I suggest that there are two useful categories to describe the ways of listening that were observed. This usually involved how the music was listened to in different situations during the festival attendance. Following that, a set of modes of encounter are delineated, which outline how listening was affecting the attendees' relationship with the music.

Before this, a brief introduction to the musical presences at the festival will be given: WOMAD, and the Africa Festival, both had three main musical stages where the musicians performed. The distinct characteristics of WOMAD were the various smaller stages with musicians or DJs playing music, while the unique characteristic of the Africa Festival was the happening of musical activities at the camping site, informally organized by the visitors themselves.

However, music at both festivals was not limited to those spaces, but was also sounding from the speakers of the different stalls all over the festival areas. Especially at WOMAD, the music seemed to be ubiquitous, and flooded the areas from the main stages, to the smaller stages, to the workshop places, up to the market, and the food and coffee trucks. Once the visitors reached the festival sites, they were continuously exposed to music, in a mix of live music from the stages and music from speakers. At the Africa Festival, there were 20 different acts performing, and at WOMAD, 110 in total.(2)

\section{Ways of Listening}

Obviously, the dense musical environment, with numerous acts and omnipresent music, could not be experienced by everyone in a uniform way, and clearly everyone had his or her own personal ways of engaging with the music. In some ways, the visitors were listening to music all the time as, even when not actively listening, our hearing capacity cannot simply be turned off. This is something which is different from, for instance, shutting our eyes.

When attending a selected performance of an artist of interest, the degree of listening attention can be described as considerably high; when aiming to buy food or beverages while there is music in the background, the degree of attention can be defined as rather low. Having a conversation, similarly, changes the dynamic. Between those two spectrums of concentration and/or attention there is a continuum with variables, and it is not possible to describe the first as an efficient 
or impactful listening, and the latter as a less efficient or meaningless listening. Here, proximity to the sound, and volume, may impact the degree of listening attention, but so may what activities the visitor is undertaking.

In her study Green concludes, that the types of listening that popular musicians engage in serve their individual goals. She also differentiates three types of listening: purposive listening, attentive listening, and distracted listening, the latter including a further type, "hearing" (Green 2002: 23-24). While the first is rather negligible for me, because it is addressing the "purposive listening" of musicians aiming to play a cover of a song, the latter two seem quite suitable to the festival experience.

"Attentive listening" is described as "listening at the same level of detail as in purposive listening, but without any specific aim of learning something in order to be able to play, remember, compare or describe it afterwards" (ibid: 24). This listening type, therefore, seems to be suitable to describe the practices of people actively listening to music. It might be music they already like, or music they are attracted to, or even music they are not yet sure that they like. From my own listening experiences, I could observe attentive listening from those three motivations, or in-between states of them.

For instance, I found myself closely following the rhythmic patterns at the performance of King Ayisoba because, knowing many of his songs from recordings, I was keen to hear the live versions of those in the concert. Another case was the performance of Parvathy Baul \& Somjit Dasgupta. Though knowing Baul's music, I had not heard her playing with Dasgupta before, but, being very interested in her music as well as in Indian classical music, I was immediately attracted to them, and enjoyed paying close attention to the details of the songs. My interviewees described their close listening experiences in similar ways to mine, but they also went beyond: Holger already had knowledge about certain styles of West African percussion, and listened to the playing of the drummers at the traditional stage with close attention:

Yeah, when I am there, I spend some time listening and watching how they play. (...) I am trying to follow the rhythmic lines, how do they do it? Ah, okay, this way! Often, I initially think "oh my god, that is too complicated" but then I see how they play and hear the rhythm and then I'm like "Ah, now I got it!". That's how it often works (Holger 2017).

Martin describes his close listening practice as related to his attitude towards music that is not immediately appealing.

From my experience, there is music, which is immediately appealing to me but there is also different music (...). For that reason, I rather try to listen for a bit longer and more deeply. I wouldn't leave the concert, if the first two songs did not convince me... I go on listening for a bit (Martin 2017).

Kelly seemed to be very attracted by certain instruments played "very well", which made her listen in more detail, and to the musical elements she connects it with. This is indicated by her use of the word "look".

I think some instruments are... more engaging than others to listen to... I love the violin played really well, be it a folk violin or a classic. And a guitar played really, really well. As in acoustic or blues or rock or if it's played really well. Instruments that are played really well. With the melody! (...) Put all that together, that's what you look for! That's what I look for (Kelly 2017). 
Attentive listening is constituted by close listening to any aspects of the music. In my case, it was the expectation about the performances of anticipated musicians that led me to listen "attentively"; for Holger, it was the desire to gain a better understanding of the rhythmic patterns; for Martin, it was related to the valuation of the music; and for Kelly, it was a desire to hear musical virtuosity.

"Distracted Listening" is described as listening while "the music is being attended to on and off, without any aim other than enjoyment or entertainment" (Green 2002: 24). Considering the ubiquity of music at the festivals, and especially at WOMAD, distracted listening would have been experienced by most visitors throughout their stay. Distracted listening may account for the majority of our musical experiences because of the amount of time in everyday life we spend listening to music for enjoyment, or without actively noticing it. According to Green, the lack of focused attention, however, would not imply this way of listening was less impactful on the listener, but instead would "form a central part of the learning process (...)" (ibid 2002: 24) That is, musical appreciation is a significant aspect of musical education. At the festival sites, the shifting between the two ways of listening should be understood as a continuum of in-between states, rather than fixed configurations.

Switching from "distracted listening" to the state of "attentive listening" could be performed quickly, for instance, when hearing something that attracts interest. It is easy to imagine that "distracted listening" is found in all contexts of musical experience. Certainly, in those cases when the festival visitor would be focused on other perceptions or activities while the music was sounding from any source in the background, the listener would be continuously exposed to the sounds, always with the possibility of some sound catching his or her attention.

From my own experience, "distracted listening" could be described as the main mode of listening, while not specifically listening to one artist but simply spending time on the festival site. Even more, for me, distracted listening served as a way to orientate oneself musically on the festival sites. Like an aural navigation, it helped to filter through the dense sound landscape, leading me to certain musical stages or places when some sound caught my interest. The statements of my interviewees were pointing at this kind of listening occurring in different situations. Anna talked about her listening to the drummers at the traditional stage in a specific sense:

I feel very much... I'm becoming peaceful when listening to the music. It's just like that... you can simply plump down into the music, it's great. (...) You don't really think about it but simply... hear the music, the rhythm and automatically respond to it. And everything around you... you forget about it (Anna 2017).

Emily told me about her way of listening to music which she finds attractive:

And that's what you look for. It's either something soothing or something... little make you move. (...) Music has to give you something. It has to either... a nice tranquil piece [is] relaxing or that you want to move [to]. I can't sit and listen to really good beat music... I can't sit! You gotta move, even if you're sitting. You gotta move. So, that's good music (Emily 2017).

Similar to the statements above, a perception mode Schippers termed "spongemethod" (Schippers 2010: 71) seemed central for Derek: "You just see someone... come and expose yourself to the fantastic music from around the world... which is what it's all about" (Derek 2017). 
"Distracted listening" was very prominent in many interview statements, though not addressed explicitly. Noteworthy, however, was the use of a set of key words signifying this mode of listening. I found words such as "plump down", "move", or "expose" referring to distracted listening during a rather passive way of being in the musical environment. Furthermore, the frequent use of the word "look" seemed to signify a suddenly occurring aural perception. While "plump down", "move", "expose" can be rather aligned to the way of distracted listening, words like "look" or "see" often were used by the interviewees to point to a notable change in the level of attention, presumably leading to more attentive listening.

So far, two ways of listening have been outlined. How they affected the listener's relationship to the music however, has yet to be determined. This is what I describe in the following section as modes of encounter. From my own observation, the 'discovery' of musicians I had not known before was a main mode of encounter during my festival attendance (Green 2002: 21, terms it "goals", "aims" or "ends"). Furthermore, the 'familiarization' with all kinds of musical styles seemed to have been equally important. Those two modes of musical encounter were also underlined by the interview statements, as well as revealing three further modes.

\section{Modes of Encounter}

\section{Discovery}

One pivotal motivation to go to music festivals might be pinned down as the curiosity to discover new music and musicians not known before. The high number of musical acts at the festivals alone made it quite likely that the visitors were encountering music they had not heard before. While my main motivation was related to conducting this research, I also got to know and value many artists that I either had not been exposed to before or knew very little about. For most of my interviewees, this seemed to be an important point. Martin described how the festival exposed him to new music:

I have listened to African music in the 80s (...) to a lot of African music (...) but recently I had only very few time for that (...). For me, this festival can result in many, many new impulses because here they both are represented, very known musicians as well as less known. And this is what I like (Martin 2017).

Karl, told me about coming to the festival to hear a specific artist, who then became sick, could not perform and was replaced by another singer. Karl ended up being happy about the accidental discovery of this new artist he would not have encountered otherwise.

It's great that the lady who yesterday replaced Sara Tavares, that she had the chance to perform on the big stage. I was very much looking forward to hear Sara Tavares... but instead I have discovered this other lady, Elida Almeida, who I have not known before. This is what I really like about it... to get to know musicians that are very new to me (Karl 2017).

In similar ways, Derek's main motivation was the discovery of new musicians: "You see someone and go 'wow, look at them' and buy the CD... or if you can't buy it there, listen on it on YouTube or maybe... yeah, discover, always discover new stuff (...)" (Derek 2017). 
There seemed to be various ways in which music or musicians were discovered, from the simple explanation that the large musical programme provided good chances of discovering new artists, to searching explicitly for unknown musicians, to accidental situations of discovery such as Karl's. These different ways of discovering something previously unknown can be connected to other music educational situations (cf. Campbell 2004: 52-53; Schippers 2010: 18). For the experience of 'discovery', both ways of listening seemed to be crucial, "attentive" as well as "distracted", though the latter probably with more emphasis.

\section{Familiarization}

Of course, listening to music led not only to a perception of something being known or unknown, but also to more complex interactions which can also be indicated here. Another pivotal mode of musical encounter involved a deeper understanding of music. Stumbling upon music that is perceived as new is a first step, but in order to become more familiar with it and understand it, more time has to be spent listening. For me, the concert of Parvathy Baul \& Somjit Dasgupta was very rewarding, in terms of becoming more aware of the rhythmic intertwinements of her singing and drumming, together with his droning instrument.

After a couple of songs, I felt myself embrace the style of the music; the "groove" or musical "feel" (cf. Green 2002: 32). For me, within this particular musical style, it was similarly an attentive listening practice. I paid attention to those musical elements, trying to grasp the wholeness of the music. Similarly, Anna pointed out that, for her, it is the longer exposure to the music that would extend her understanding:

You don't really think about it but simply... hear the music, the rhythm and automatically respond to it. And everything around you... you forget about it. I have been here before... and I know it already. But I like again... to have further insight into the music (Anna 2017).

Susanne told about her affiliation with Malian music, which started with a discovery, but then developed over the years of attendance at the festival.

There [, at the small stage,] are very nice acts and for me it's always like a treasure chest which I'm searching through and then I buy the CDs, read about it and listen to it a lot. (...) And [over the years] I have got to know and appreciate the music from Mali here. I did not know them before (Susanne 2017).

Karl again talked about discovering the singer Elida Almeida, but now in ways that explained why he was so touched by the musical "feel" (Green 2002: 32).

The singer from the Cap Verdes... she was a bit nervous (...) But for me, it had something true. She was also very happy about the applause and then there was something between her and the audience, something very authentic. You could simply feel how she loves the singing and her music has transmitted something (Karl 2017).

What becomes apparent when considering these two modes of musical encounter is that the temporality appears as an important factor for both: the discovery, and the familiarization. While the 'discovery' mode of encounter points to a sudden event in a relatively short time-period, the familiarization mode of encounter seems 
to take very different timeframes, from durations of minutes (Anna) to those of years (Susanne).

Apart from those two modes of encounter, the music listening also let the festival visitors develop their valuation of certain musical styles, places at the festival site, or ways to experience the festival. For all the interviewed visitors, the more often they attended the festival, the better they knew what music they liked and where to find it, leading to a transformative festival experience.

At the Africa Festival, nearly all of the visitors who had regular attendance named the camping site as a significant factor in their choice to attend the festival. Some even totally preferred the camping site; as Susanne notes: "[W]ithout the camping site something important is missing... I would never come only for the festival site" (Susanne 2017). Similarly, the musical criteria were developed in individual ways, but despite this, the people seemed to be open and sensitized to unusual kinds of music. Some of the interviewees, especially Martin and Holger, had a quite tenacious approach to this, giving every kind of music a certain timeframe to convince them before judging.

One, if not the most important mode of encountering the music has not yet been named, though it is the most obvious one as well as the condition for the other: the experience of enjoyment. It is the main motivation to go to music festivals, but it is also much more than that. It has infused all the ways of listening, or modes of musical encounter, conscious or unconscious, at the festivals (cf. Green 2002: 104107).

From the discovery or familiarization with, and the valuation or sensitization towards music, all was dependent on some kind of enjoyment. After all, music festivals are deliberately attended by visitors. And while enjoyment is not always related to learning, and in formal music education can even be opposed to it, it is strongly related to the learning practices of popular musicians, as Green states: "(...) [E]njoyment was, as has already been made apparent, a major aspect of all the musicians' learning practices" (ibid 2002: 104). In many of the interview statements quoted above and below, it is addressed either explicitly or implicitly, often through words such as "like", "love", "interest", and so on, and, therefore, it will not be quoted here again.

\section{Festivals of World Music}

As outlined earlier, music is central to the festival experience. When visiting a festival, one is in the midst of an immersive experience, addressing not only the auditory but the whole of perception. Apart from the auditory, the festival experience was strongly influenced by the visual and haptic perceptions, the senses of smelling and tasting, as well as various forms of social interaction. One crucial aspect of a festival experience that relies on multisensory perception has so far been left out, and will be approached now. From my case studies, the question arises: what is 'world music' in this context, who is encountering whom, and how is it perceived by the festival visitors? Although I cannot untangle the history of 'world music' entirely in this article, some consideration of the term will help a further understanding of how education works in the world music festival experience.

World music festivals present music in the constructed genre of 'world music', which in this form is quite a recent phenomenon. World music is not simply the music of the world, but a genre category that was invented in 1987 by a number of record labels (fRoots Magazine 2000; Frith 2000). From then on, music that was formerly organized in categories such as 'roots', 'traditional', 'ethnic', or 
'international' (Anderson 2000) had a new label under which to be promoted, sold and consumed. Though it might be an issue for other pop music festivals as well, for world music it is one, if not the central appeal: the perception of difference between self and 'Other' (cf. Hall 1997: 225; Carfoot 2016: 181; Reimer 1991: 56; Hutnyk 1998: 411).

Similar to those former music categories, the music in 'world music' is constituted mainly by the difference of the people making the music from those consuming it: World musicians are often perceived as 'others', mostly from nonWestern countries, and particularly from Africa, while the audience predominantly is described as Western, white, and middle class (cf. Taylor 2004; Guilbault 2001; Hutnyk 1998). The perceived difference, furthermore, is created and maintained through various parameters that could be termed 'signifiers' of world music (cf. Lell 2019). Those may refer to a musical difference, such as 'exotic' musical styles, instruments, or rhythms, or to a visual difference from the musicians' ethnicity, ways of appearing, or performing. Also, the music is often promoted as being universally understood across languages and national borders, and thus as providing intercultural understanding (cf. Ibid.; White 2012: 190-206).

Drawing on these parameters, world music has a rather harsh standing in ethnomusicology, where it is often seen suspiciously as the commodification of a musical 'Other' that is financially and culturally exploited for the entertainment of a Western audience (cf. White 2012: 190-206; Taylor 1997: 16-17; Feld 2000: 151-154, 165-171; Carfoot 2016: 181). Although there are attempts to balance this opinion (Haynes 2005: 381; Krueger 2011: 298-299), the predominant academic perspective on world music follows these pessimistic terms.

So far, the problematic issues surrounding world music have been left out for good reasons. The ideas I have presented, about the festivals functioning as places of musical education, are complicated by the discourse of 'world music' that frames the musical encounters. This pivotal issue will be addressed now. What notion of world music was presented at the festivals? How did the festival visitors perceive it?

Outlining an ethnographic perspective gained from observation, the festivals could easily be seen rather critically because in many ways they seemed to be feeding the notion of world music as the music of an ethnic, religious, exotic, or geographic 'Other', firmly different from the audience perceiving it. Taking the interview statements into consideration, however, this assumption was challenged.

Although many of my interviewees were reproducing ideas of 'Othering', as was the festival environment presenting them, such as highlighting the perceived difference of the musicians that were appealing to them, they often transcended these thoughts. Rather, they showed awareness about the possible contradictions of what was offered to them, and about how that musical experience was shaped. Here, their self-reflexivity stood out, as well as their ambitions to improve on the problems of their participation in this sort of framing discourse.

Dan, Karl and Martin questioned the term 'world music', and how appropriate it was. Martin suggested the term was "deceptive" (2017), while for Karl the term was "negative in the sense of being used for music that is spiced up with aspects of other cultures" (2017). Derek went to the very first WOMAD in 1982, and reflected about the festival's audience back then and today:

I think it's still very white. I think if you look around at the demographic. Yeah, I mean there is not a huge... you know ethnic mix or diversity. Here are predominantly white people. (...) it's a middle-class festival, really, (...) (Derek 2017). 
Marina told me about her love for traditional percussion music, and still she showed her awareness of the aspect of commodification of world music:

It is African world music, which you can hear here. (...) but it is rather adapted to our European or German ears, all of that (...) What you can hear at the stages, is already adapted to European ears. And I think that is why the musicians are so successful (Marina 2017).

Ellen made clear that, despite the festivals strongly promoting this aspect, she would rather not see them as being useful to foster tolerance:

I am not sure about that. The people who come here they already are - I think - tolerant. And I'm not sure if the festival actually is communicating these things to external people. Those who have their own opinion and are not interested in other cultures... do not come here (Ellen 2017).

The perception of the world music genre turned out to be more self-reflexive and critical than I had expected from mere observation. Many interviewees showed an awareness of underlying discrepancies, although the festival was not addressing them in any way. Furthermore, throughout most conversations, the interviewees reflected a strong interest in the musicians' and peoples' lives, their musical heritage, and the struggles they might go through. This seemed to be happening despite the simultaneous 'Othering' of them. What the interviewees expressed could be related to the hopes of intercultural encounter, of "enhance[ing] more (...) humanitarian views (...) coupled with a moral obligation to others" (Krueger 2011: 299).

This point opened up highly interesting questions about the ways the interviewees perceived an explicitly presented musical 'Other'. Their statements reveal perspectives on the experience of world music at the festivals firmly as more complex than those that would be gained from a simple ethnographic analysis of the festival environment, the advertising, the representation of the musicians, and so on. It opposes the perspective often taken on the world music audience, as being naïvely celebrating the 'Other', and outlines the educational potential of the festivals fostering critical awareness. These findings resemble recent discussions on the relationship between (popular) music and postcolonialism (Lund 2019; Lovesey 2017; Barrett 1996) and invite further investigation.

\section{World Music Festivals as Music Educational Sites}

To summarize, this paper has outlined how world music festivals can be seen as places of musical education. First, from a notion of music education as a formal institutional practice, only the workshops at WOMAD, and the camping site music making at the Africa Festival could be seen as music educational. This, however, would leave out the most impactful form of music learning, reaching a wide audience, and happening at the festival sites, amid the ubiquitous music, between the stages, between the market stalls, and next to all the other festival attendees. Therefore, second, the idea of music education was extended to suit the field of music festivals, opening up further ways of understanding. Building on Green, (2002) and on data from ethnographic research including interviews at WOMAD and the Africa Festival, various practices of learning could be described, which illuminate the music educational value of the visitors' experiences. 
This refers to two ways of listening and several modes of encounter which are outlined, detailing the interactions between the festival visitors and the musical environment of the festivals. The ubiquity of music throughout both festivals made encounters of visitors with music inevitable. The findings suggest that two types of "attentive" and "distracted listening" have been utilized by the festival visitors during their interactions with the music, the first describing more focused listening to particular musicians or musical elements, and the second referring to a more unconscious way of perceiving the music holistically.

Additionally, various modes of encounter could be identified, which outline how listening was affecting the attendees' relationship with the music. The most important were found to be the discovery of new music, and the familiarization with any kind of music. Within those modes of encounter, temporality seemed to play a crucial role, ranging from quick, on-the-spot discoveries of new music, to long-term, deeper understandings of music. Discoveries, furthermore, could occur in different ways, either rather predictably, when there is an expectation of discovering something new, up to more accidental ways, when the discovery was not foreseeable. Apart from that, the preference for certain musical styles, or attractive places at the festival, as well as the openness and sensitization to unusual kinds of music, and, finally, the sheer enjoyment of the music, were found to be further modes of encounter.

The festivals' relation to the genre of 'world music' was further analysed. The festival environments were seen to present a very specific, one-sided notion of 'world music'. Therefore, it was surprising how many interviewees showed themselves to be largely aware of the contradictions within the genre, even though it was not the subject of the festivals at all. This awareness could apply to the term 'world music', to the commercial genre category, the intended audience, or to the promises of intercultural understanding. Confronting these issues surrounding 'world music' is seen to be a major topic to learn about when dealing with the genre of world music, and therefore shows a further, music educational value of world music festivals. (cf. Krueger 2013: 94)

The present analysis of WOMAD and the Africa Festival helps to demonstrate the potential of festivals as places of musical education. This research contributes to the emerging field of music festival studies, and sheds light on an area yet barely covered. Providing various formative and descriptive parameters, a model has been outlined that enables one to describe the music educational experiences of the music festival visitors. The two case studies can be valuable sites of musical education, enabling an intensive engagement with the music, with the possibility to further interrogate the term 'world music', and the framing of experiences that are more self-reflexive for visitors than perhaps the producers imagine.

The results further shape our understanding of an idea of music education beyond formal and institutional structures, and of how people learn musically, without necessarily acquiring practical music skills, namely musical appreciation. Further research is suggested, in order to sharpen our understanding of the ways that music learning happens at music festivals and in other similar settings. Ultimately, this will not only contribute to the discourse of music education and music festival studies, but may be used to develop a framework providing policymakers and event managers with insights into how to design better festival settings, and programmes which, not least, can ensure the flourishing of music educational experiences. 


\section{Endnotes}

(1) I am aware of the different ways to write world music / World Music, but as the differentiation becomes increasingly difficult and this question should not be the focus of this paper, I will use world music without capital letters.

(2) For the Africa Festival music programme, see

https://www.africafestival.org/29-africa-festival-2017

For the WOMAD music programme, see

https://www.efestivals.co.uk/festivals/womad/2017/lineup.shtml

\section{References}

\section{Bibliography}

Amico, M. 2014. The Staged Desert: Tourist and Nomad Encounters at the Festival au Désert. In S. Krüger and R. Trandafoiu Eds. The Globalization of Musics in Transit. Music Migration and Tourism. London and New York: Routledge: 86-100.

Anderton, C., 2018. Music Festivals In The UK: Beyond The Carnivalesque. Andover: Routledge.

Barrett, J. 1996. World Music, Nation and Postcolonialism. Cultural Studies 10: 237-247.

Bohlman, P. 2002. World Music: A Very Short Introduction, Oxford: Oxford University Press.

Brás, N. et al. 2019. How Do Residents Experience Their Own Festivals? A Qualitative Approach to Meanings and Experiences. In J. Mair Ed. The Routledge Handbook of Festivals. New York: Routledge: 263-272.

Campbell, P. S. 2004. Teaching Music Globally, Experiencing music. Experiencing Culture. Oxford: Oxford University Press.

Carfoot, G. 2016. Musical Discovery, Colonialism, and the Possibilities of Intercultural Communication through Music. Popular Communication 14: 178186.

Colwell, R. and C. Richardson 2002. The New Handbook of Research on Music Teaching and Learning. Oxford: Oxford University Press.

Duffy, M. 2019. Music Events and Festivals. Identity and Experience. In J. Mair Ed. The Routledge Handbook of Festivals. New York: Routledge: 304-312.

Feld, S. 2000. A Sweet Lullaby for World Music. Public Culture 12: 145-171.

Frith, S. 2000. The Discourse of World Music. In G. Born and D. Hesmondhalgh Eds. Western Music and its Others: Difference, Representation, and Appropriation in Music. Berkeley: University of California Press: 305-322.

Green, L. 2002. How Popular Musicians Learn. A Way Ahead for Music Education. Aldershot: Ashgate.

Guilbault, J. 2001. World music. In S. Frith, W. Straw and J. Street Eds. The Cambridge Companion to Pop and Rock. Cambridge: Cambridge University Press: 176-210.

Hall, S. 1997. The Spectacle of the 'Other'. In S. Hall Ed. Representation: Cultural Representations and Signifying Practices. The Open University: Sage Publications: 223-291.

Haynes, J. 2005. World Music and the Search for Difference. Ethnicities 5: 365385.

Howard, K. 2009. Live Music vs Audio Tourism: World Music and the Changing Music Industry. London: School of Oriental and African Studies. 
Hutnyk, J. 1998. Adorno at Womad: South Asian Crossovers and the Limits of Hybridity-Talk. Postcolonial Studies 1 (3): 401-426.

Karlsen, S. and S. Brändström 2008. Exploring The Music Festival As A Music Educational Project. International Society for Music Education 26 (4): 363-373. http://dx.doi.org/10.1177/0255761408096077

Koopman, C. 2007. Community Music As Music Education: On The Educational Potential Of Community Music. International Society for Music Education 25 (2): 151-163. http://dx.doi.org/10.1177/0255761407079951

Krueger, S. 2011. Democratic Pedagogies: Perspectives from Ethnomusicology and World Music Educational Contexts in the United Kingdom. Ethnomusicology 55: 280-305. http://dx.doi.org/10.1017/S0261143000005535

Krueger, S. 2013. Undoing Authenticity as a Discursive Construct: A Critical Pedagogy of Ethnomusicology and 'World Music'. In: B. Alge and O. Krämer Eds. Beyond Border: Welt-Musik-Pädagogik: Musikpädagogik und Ethnomusikologie im Diskurs. Augsburg: Wissner: 93-114.

Leggewie, C. and E. Meyer, Eds. 2017. Global Pop, Das Buch zur Weltmusik. Meppel: J.B. Metzler.

Lell, P. 2019. "Come and Expose Yourself to the Fantastic Music from Around the World": Experiencing World Music Festivals. In G. Peres da Silva and K. Hondros Eds. Music Practices Across Borders: (E)valuating Space, Diversity and Exchange. Bielefeld: Transcript: 85-104.

Lovesey, O. 2017. Decolonizing the Ear: Introduction to "Popular Music and the Postcolonial". Popular Music and Society, 40 (1): 1-4.

Mair, J. Ed., 2019. The Routledge Handbook of Festivals. New York: Routledge.

McKay, G. 2015. The Pop Festival: History, Music, Media, Culture. New York: Bloomsbury Academic.

McPherson, G. and G.F. Welch, Eds. 2012. The Oxford Handbook Of Music Education. Oxford: Oxford University Press.

Näumann, K. 2017. Weltmusikfestivals und Festivalisierung der Weltmusik. In C. Leggewie and E. Meyer Eds. Global Pop, Das Buch zur Weltmusik. Meppel: J.B. Metzler: 204-212.

Paleo, I. O. and N. M. Wijnberg, 2006. Classification of Popular Music Festivals: A Typology of Festivals and an Inquiry into Their Role in the Construction of Music Genres. International Journal of Arts Management 8 (2): 50-61.

Reimer, B. 1991. Selfness and Otherness in Experiencing Music of foreign Cultures. The Quarterly 2 (3): 4-13.

Schippers, H. 2010. Facing the Music. Oxford: Oxford University Press.

Snell, K. 2005. Music Education Through Popular Music Festivals: A study of the OM Music Festival in Ontario, Canada. Action, Criticism, and Theory for Music Education 4 (2): 1-35. http://act.maydaygroup.org/articles/Snell4_2.pdf

Solis, T., Ed. 2004. Performing Ethnomusicology. Teaching and Representation in World Music Ensembles. London: University of California Press.

Swanwick, K. 2016. A Developing Discourse in Music Education. Selection Works of Keith Swanwick. New York: Routledge.

Taylor, T. 1997. Global Pop. World Music, World Market. London: Psychology Press.

Taylor, T. 2004. Bad World Music. In C.K. Washburne and M. Derno Eds. Bad Music, The Music We Love to Hate. New York: Routledge: 65-81.

Taylor, T. 2017. Music in the World. Selected Essays, Chicago: University of Chicago Press. 
Veblen, K. K. 2012. Adult Music Learning in Formal, Nonformal and Informal Contexts. In G. McPherson and G.F. Welch Eds. The Oxford Handbook Of Music Education, Volume 2, Oxford: Oxford University Press: 243-254.

Volk, T. 1998. Music, Education and Multiculturalism. Foundations and Principles. Oxford: Oxford University Press.

White, B. 2012. The Promise of World Music: Strategies for Non-Essentialist Listening. In B. White Ed. Music and Globalization. Critical Encounters. Indiana: Indiana University Press: 189-217.

\section{Web Sources}

29 Africa Festival 2017. https://www.africafestival.org/29-africa-festival-2017. Accessed: 30 August 2019.

Anderson, I. 2000. World Music History. fRoots Magazine. https://frootsmag.com/world-music-history. Accessed: 30 August 2019.

fRoots Magazine 2000. Press Release 01 - World Music. https://frootsmag.com/press-release-01-world-music. Accessed: 30 August 2019.

Lund, H. 2019. Decolonizing Pop Music. http://norient.com/stories/decolonizingpop-music/. Accessed 30 August 2019.

Songlines 2018. International World Music Festival Guide 2018-2019. https://reader.exacteditions.com/issues/61993/spread/1. Accessed: 30 August 2019.

WOMAD 2018 Website. https://womad.co.uk/workshops/. Accessed: 20 January 2019.

WOMAD 2017 Line-up.

https://www.efestivals.co.uk/festivals/womad/2017/lineup.shtml. Accessed: 30 August 2019.

\section{Interviews}

Anna. 2017. Interviewed by the Author, Africa Festival Würzburg, 27 May. Ellen. 2017. Interviewed by the Author, Africa Festival Würzburg, 28 May. Holger. 2017. Interviewed by the Author, Africa Festival Würzburg, 27 May. Karl. 2017. Interviewed by the Author, Africa Festival Würzburg, 27 May. Marina. 2017. Interviewed by the Author, Africa Festival Würzburg, 28 May. Martin. 2017. Interviewed by the Author, Africa Festival Würzburg, 27 May. Susanne. 2017. Interviewed by the Author, Africa Festival Würzburg, 28 May.

Dan. 2017. Interviewed by the Author, WOMAD Charlton Park, 29 July. Derek. 2017. Interviewed by the Author, WOMAD Charlton Park, 29 July. Emily. 2017. Interviewed by the Author, WOMAD Charlton Park, 28 July. Kelly. 2017. Interviewed by the Author, WOMAD Charlton Park, 28 July. 